\title{
Preparing Pre-Service Teachers for Mathematics Teaching at Primary Schools in Vietnam
}

\author{
Phan Thi Tinh ${ }^{1}$, Trinh Thi Tuyet Le ${ }^{2 *}$, Phuong-Thao Nguyen ${ }^{3}$, Cuong Duy Le ${ }^{2}$, Manh-Tuan Nguyen ${ }^{4}$, \\ Tien-Trung Nguyen ${ }^{5,6}$ \\ ${ }^{1}$ Hung Vuong University, Phu Tho, VIETNAM \\ 2 Dong Thap University, Dong Thap, VIETNAM \\ ${ }^{3}$ An Giang University, Vietnam National University Ho Chi Minh City, An Giang, VIETNAM \\ ${ }^{4}$ Hanoi National University of Education, Hanoi, VIETNAM \\ ${ }^{5}$ Institute of Theoretical and Applied Research, Duy Tan University, Hanoi 10000, VIETNAM \\ ${ }^{6}$ Vietnam Journal of Education, VIETNAM
}

Received 17 July 2020 - Accepted 27 January 2021

\begin{abstract}
This article aims to identify the professional competencies that primary school teachers in Vietnam need for effective mathematics teaching and the extent to which teacher-training colleges prepare pre-service teachers with those competencies. A mixed method approach with an explanatory sequential design was employed. Questionnaires were sent to 493 pre-service teachers and interviews were conducted with 20 teacher trainers from five major teacher-training colleges in Vietnam. The findings indicated that Vietnamese pre-service teachers were adequately trained in terms of mathematical content knowledge yet were less ready in terms of mathematical teaching pedagogies. Mathematical pedagogical content knowledge was reportedly an often-neglected area at teacher-training colleges and was subsumed under general pedagogical content knowledge. The study has both theoretical and practical contributions to the development of professional qualities for primary school teachers teaching mathematics at primary school in Vietnam.
\end{abstract}

Keywords: professional competencies, teacher education, pre-service teachers, primary school teachers, mathematics teaching, competency-based education approach

\section{INTRODUCTION}

Mathematical Literacy and Professional Competencies of Mathematics Teachers

As a country that has recently transformed from one of the world's poorest to one of the most dynamic emerging economies in East Asia, Vietnam considers education and training as a vital means of achieving socio-economic progress. The country allocates annually a fifth of its national budget to investments in the education sector and has launched important initiatives in reforming teaching and learning across school levels. With this, it has claimed successes in widening educational access and ascertaining educational equality, for example by maintaining a 95\% net enrolment rate for primary school, a $98 \%$ literacy rate for Vietnamese aged between 15 and 60, and progressing towards universalising its secondary education (Vietnam National Assembly, 2016).

Having expanded the quantitative dimension of its school education, Vietnam is now shifting its policy focus to quality aspects. The National Education for All Action Plan 2003-2015, for example, is among the government's recent efforts to "improve all aspects of the quality of education and ensure excellence of all so that recognised and measurable learning outcomes are achieved by all, especially in literacy, numeracy and essential life skills" (Vietnam Ministry of Education and Training, 2018). The General Education Renovation Project funded by World Bank (2014), meanwhile, has

(c) 2021 by the authors; licensee Modestum. This article is an open access article distributed under the terms and conditions of the Creative Commons Attribution License (http://creativecommons.org/licenses/by/4.0/). 


\section{Contribution to the literature}

- The study situates the construct of mathematical teaching competence in the context of Vietnam's primary school education.

- The study contributes to an understanding of pre-service teachers' readiness to teach mathematics at primary school from the perspectives of pre-service teachers and teacher-training institutions.

- The study gives implications about enhancing professional competencies for pre-service teachers.

been implemented with the hope of upgrading traditional teaching pedagogies to a competency-based

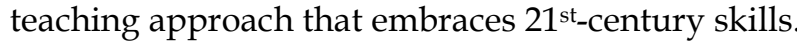

Almost every important policy document addressing the quality dimension of the education sector in Vietnam recognises teacher quality and classroom instruction as the key factor to success. The government clearly articulates in its agendas and action plans a strong commitment to upgrade, motivate, and empower schoolteachers. For example, under the Strategy for Educational Development 2001-2010, two leading teacher training institutions are assigned the tasks of training high-quality teachers; 200 teacher training institutions are reorganised into 90 to better mobilise qualified trainers and modern teaching facilities; colleges that train teachers for remote and ethnic areas are set up provincially and provided with more funding; and remuneration policies are formulated to better support teachers financially. Between 2007 and 2013, the percentages of teachers having state-required qualifications rose from $95.87 \%$ to $99.69 \%$ for primary education and from $89.53 \%$ to $93.33 \%$ for secondary education. Most recently, in 2018, MOET introduced a set of national standards for schoolteachers, aiming for this to act as a platform in fostering teachers' competencies and professional development (Vietnam Ministry of Education and Training, 2018).

While the policy environment in Vietnam is highly facilitative, teacher standards and teacher education are not yet responsive to changing skills needs from basic numeracy and literacy skills to high-order hard and soft skills that can cater to Vietnam's economic development. Reforms of pedagogical approaches, dated as early as the 1990s, seek to shift teacher-centred to student-centred teaching and equip teachers with new classroom strategies such as collaborative or active learning (Do, 2000). However, presently, one-way lecturing, heavily theoretical curriculum, rote-learning, and an overreliance on textbooks are still the norms (Nguyen, Trinh, \& Tran, 2019). According to a survey by Hanoi National University of Education, only $20 \%$ of Vietnamese teachers are competent classroom teachers who have deep subject knowledge and a wide pedagogical repertoire that can meet new curriculum and pedagogical demands (Do, 2020). Teachers equate the shift from traditional practices to new instructional capacity and expertise with a complex endeavour which they lack the materials and support to make (Nguyen et al., 2019).

This paper is situated within a teacher-upskill project conducted in 2018 to support Vietnamese teachers with mathematics teaching at the primary school level. The project comprises two stages, firstly to examine how teacher-training colleges cater to pre-service teachers' professional needs and secondly to design intervention strategies that can better support pre-service teachers in performing their teaching duties. This paper particularly reports the findings from the first stage of the project whose objectives were to identify the skills and knowledge that primary school teachers in Vietnam need for effective mathematics teaching and explore the extent to which teacher education develops, for teachers, such expertise. Regarding the structure, the paper begins with a review of models of professional competencies of mathematics teachers and identifies the gap in research on mathematics teacher education, particularly in the context of Vietnam primary education. The paper then presents the methodology, including the approach to developing a competency framework for Vietnamese mathematics teachers and a research instrument employed to explore pre-service teachers' training needs. The paper reports relevant findings in the last section before drawing together in the conclusion several recommendations for teacher-training institutions.

\section{Mathematical Literacy and Professional Competencies of Mathematics Teachers}

The importance of mathematical literacy is recognised in all education systems in the world, particularly given that the present-day technological advances and global economy greatly depend on mathematically skilled manpower. Mathematical literacy is not only crucial to a nation's social and economic progress but also promotes the development of human beings as individuals. The $\operatorname{OECD}(1999$, p. 50) emphasises the presence of mathematics in various facets of an individual's endeavour, namely their "current and future private life, occupational life, social life with peers and relatives, and life as a constructive, concerned and reflective citizen". 96\% of students from 38 countries that participate in Third International Mathematics and Science Study (TIMSS) who were surveyed also rated being mathematically competent as a valuable asset (Leung, 2006). Due to the critical importance of mathematics, a wealth of literature has 
examined the components of mathematical literacy to cast light on how students learn mathematics and what expertise a teacher will need to support students' successful mathematics learning.

From a componential perspective, mathematical proficiency is seen to comprise five strands (Barham, 2020; Superfine \& Li, 2014). The first strand - conceptual understanding - refers to students' understanding of mathematical symbols, visualisation, concepts, operations, and relations. To develop this strand for students, teachers are required to not only master mathematical knowledge elaborated in the curriculum but only know how students construct their learning, and from then, employ suitable pedagogies to help students perceive the concepts and their connections. The second strand - procedural fluency - refers to students' ability to perform mathematics processes in a precise, efficient, and suitable manner. Teachers need both the skills of performing mathematical operations and an understanding of students' errors to help students acquire procedural fluency. Thirdly, the strategic competence concerns students' capability of formulating and solving mathematical problems. Teachers need to equip students with problem-solving strategies, logical thinking, pattern identifying, and methods of numerical or graphical representation to handle specific mathematical problems. The fourth strand of mathematical proficiency - adaptive reasoning concerns a high-level thinking ability of students to logically reflect on, explain for, and justify the occurrence of phenomena. Classroom instruction necessarily involves opportunities for students to estimate, model, predict, and critique by means of intuitive, deductive and indictive reasoning. Finally, productive disposition concerns the inclination to understand and interpret the world in mathematics and value the usefulness of mathematics. Teachers need to develop for students their confidence, positive thinking, and appreciation of mathematics to have this strand of mathematical proficiency.

Unpacking students' mathematical proficiency from a componential view as above is useful in identifying mathematics teachers' professional competencies, determining their professional needs, and designing teacher professional development programmes. However, from a teacher-training perspective, the mathematical literacy and pedagogical knowledge that teachers need tend to overlap when teachers cater to students' development of those five strands. For example, improving students' conceptual understanding and procedural fluency both demands teachers' mathematical literacy, understanding of students' cognitive processing, and the use of suitable pedagogies. In this case, the work of Shulman $(1986,1987)$, which identifies professional competencies required of teachers by domains, is useful.
Shulman (1986, 1987) developed a model of teacher knowledge that comprises seven categories, namely (a) content knowledge, (b) general pedagogical knowledge, (c) pedagogical contents knowledge (PCK), (d) curriculum knowledge, (e) knowledge of learners and their characteristics, (f) knowledge of educational context, and (g) knowledge of educational ends, purpose, and value and their philosophical and historical grounds. Many large-scale studies on the professional development of mathematics teachers, such as the Teacher Education and Development Study in Mathematics (TEDS-M) (Figure 1) (Blömeke, Hsieh, Kaiser, \& Schmidt, 2014), have built on the theoretical framework of Shulman $(1986,1987)$ to evaluate the effectiveness of teacher education. Many of these studies intensively focus on the cognitive aspects of mathematics teachers' professionalism.

In the TEDS-M framework, mathematics content knowledge (MCK) refers to the main mathematical subdomains of algebra, geometry, number, and data. Mathematics pedagogical content knowledge (MPCK), meanwhile, falls under two sub-domains, the first being curricular knowledge and knowledge for planning for mathematics teaching and the second being knowledge of implementing mathematics for teaching and learning. The TEDS-M considers the MPCK to be heavily influenced by tradition-bound and culture-bound expectations of teachers' core teaching duties (Kaiser et al., 2017). It, therefore, includes also the affectivemotivational aspects of teachers to examine the quality of teacher training. The TEDS-M adopts a developmental approach to defining the MCK and MPCK for novice to expert mathematics teachers (Table 1), which is useful for the identification of the professional competencies required of Vietnamese mathematics teachers in this study.

Many other competency models also highlight the importance of MCK and MPCK. Moore and Rossiter (2018) refer to this as "specialised content knowledge" (SCK). As explained by Ball (2003, p. 4), "knowledge of mathematics for teaching entails more than knowing it for oneself [but] requires being able to unpack ideas and make them accessible as they are first encountered by the learner, not only in their finished form". Early on, Shulman (1986, p. 9) also argues that this SCK "goes beyond knowledge of subject matter per se to the dimension of subject matter knowledge for teaching". Therefore, there have been efforts to specify the SCK. The Mathematical Knowledge for Teaching (MKT) framework developed by the University of Michigan combines the content knowledge and pedagogical content knowledge into the mathematical knowledge for teaching yet suggests that these function act as distinct, non-overlapping domains (Hauk, Toney, Jackson, Nair, \& Tsay, 2014). Under this framework, content knowledge comprises common content knowledge, specialised content knowledge and horizon content 


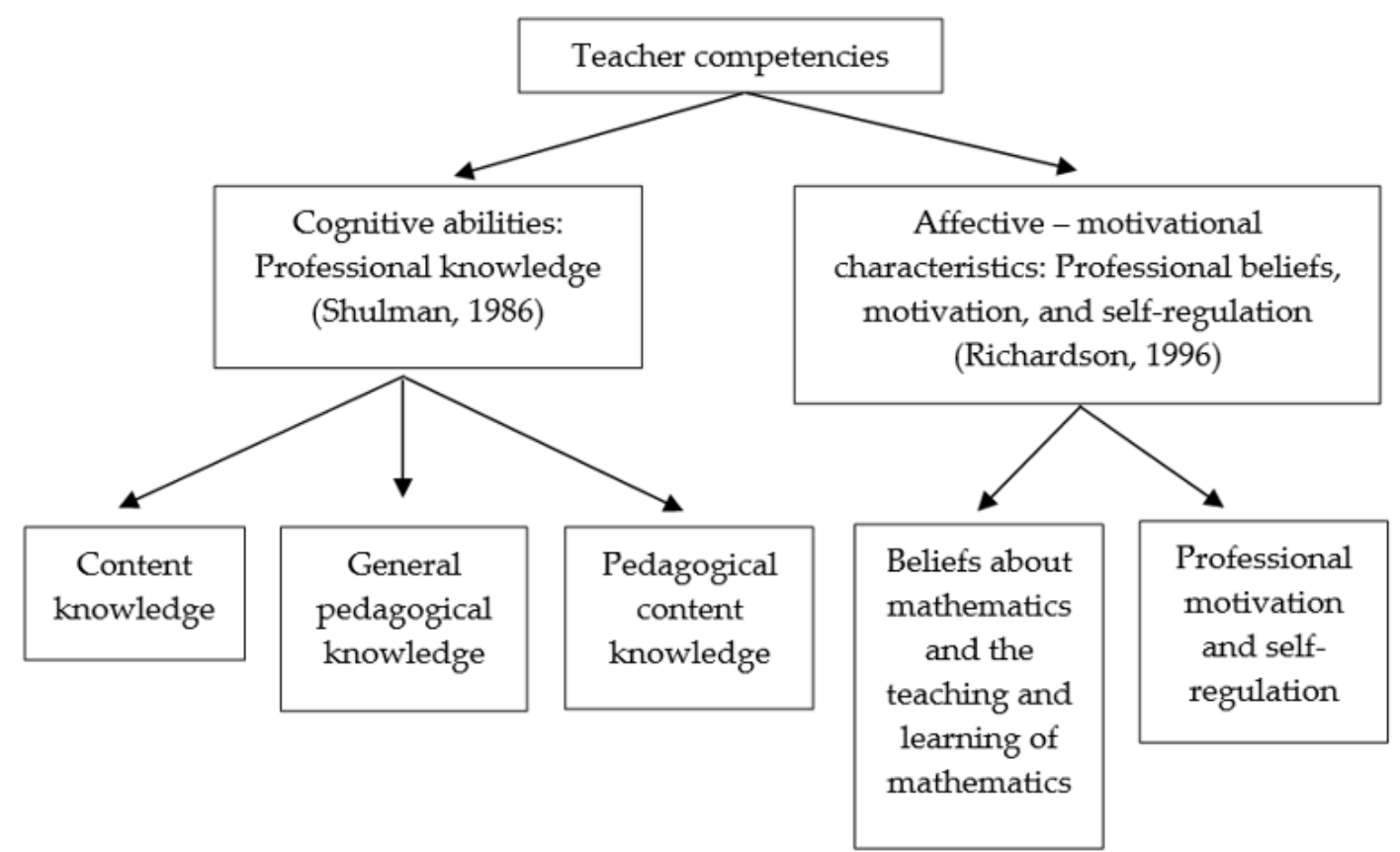

Figure 1. TEDS-M conceptual model of mathematics teachers' professional competencies (Döhrmann, Kaiser, \& Blömeke, 2012, p. 327)

Table 1. Mathematics professional competencies by levels of expertise for primary school teachers (Kaiser et al., 2017, pp. 169-170)

\section{Expert}

- Possessing deep mathematical curricular knowledge

- Possessing strong structural knowledge in different mathematical areas

- Possessing mathematical argumentation and logical reasoning skills

Competent

- Possessing sound mathematical knowledge

$\Sigma$ - Possessing a developed insight about fundamental mathematical ideas

- May experience problems using argumentation and logical reasoning in advanced mathematics problems

Novice

- Having limited structural insight in mathematics

- Often being challenged by example-bound argumentation

Expert

- Easily interpreting students' answers and recognising their cognitive challenges

- Easily identifying and employing a suitable teaching strategy for a teaching sequence

Novice

- Having limited ability to recognise the correctness of students' answers

- Having limited ability to judge the adequacy of specific teaching strategies

knowledge. Pedagogical content knowledge, meanwhile, comprises knowledge of content and students, knowledge of content and teaching, and knowledge of the curriculum. These frameworks serve as a useful point of reference for this study.

\section{Mathematics Teachers' Professional Needs}

The literature on education shares a strong agreement regarding the critical role of teacher quality to students' learning outcomes. The Australian policy discourse, for instance, considers teachers as the "single greatest in-school influence on student achievement" (Teacher Education Ministerial Advisory Group, 2014), which Hattie (2003) quantifies to account for almost a third of the variance in student success. On observing countries' performance in the Programme for International Student Assessment (PISA), the OECD (2010) also remarks that PISA high-performing education systems tend to systematically prioritise the quality of teachers. In mathematics teaching, the relationship between teachers' mathematical knowledge and students' mathematics achievement has been acknowledged in the literature (for example Moore \& Rossiter, 2018). Campbell et al. (2014), after controlling student and teacher-level characteristics variables, found a positive correlation between mathematics teachers' subject matter knowledge and their students' success in mathematics tasks. Baumert et al. (2010) came to similar findings and further added that teachers' MPCK contributes positively to students' gains in the 
Table 2. Primary school subjects by grade level (in number of lessons per one school year)

\begin{tabular}{|c|c|c|c|c|c|}
\hline \multirow{2}{*}{ Subjects } & \multicolumn{5}{|c|}{ Grades } \\
\hline & 1 & 2 & 3 & 4 & 5 \\
\hline Vietnamese & 420 & 350 & 280 & 245 & 245 \\
\hline Mathematics & 105 & 175 & 175 & 175 & 175 \\
\hline Foreign language & & & 140 & 140 & 140 \\
\hline Ethics & 35 & 35 & 35 & 35 & 35 \\
\hline Nature and society & 70 & 70 & 70 & & \\
\hline History and geography & & & & 70 & 70 \\
\hline Computer science and technology & & & 70 & 70 & 70 \\
\hline Physical education & 70 & 70 & 70 & 70 & 70 \\
\hline Arts & 70 & 70 & 70 & 70 & 70 \\
\hline Experiential activities & 105 & 105 & 105 & 105 & 105 \\
\hline Minority language (optional) & 70 & 70 & 70 & 70 & 70 \\
\hline Foreign language (optional) & 70 & 70 & & & \\
\hline Total number of lessons per school year & 1015 & 1015 & 1085 & 1120 & 1120 \\
\hline Average number of lessons per week & 29 & 29 & 31 & 32 & 32 \\
\hline
\end{tabular}

subject. This highlights the importance of preparing and credentialing teachers so that they can have a positive impact on student learning.

For mathematics teaching, understanding the subject matter and subject-specific pedagogies is central to effective teachers' practices and should form the core elements of teacher training (Moore \& Rossiter, 2018). The "No Child Left Behind" Act of 2001, for example, demands that all schoolteachers are highly qualified in their subject matter. The Act also demands teachertraining institutions to prepare future teachers for fulfilling their teaching duties. However, the development of mathematics teachers' professionalism during the training of pre-service mathematics teachers is known to be challenging due to the missing connection between university training and school teaching. Richardson (1996), for example, criticises university education of mathematics teachers as a weak intervention compared with the practical school experience and professional socialisation that a teacher is exposed to. Kaiser et al. (2017), likewise, agree that there exists a gap between university mathematics and school mathematics, therefore seeing university education as having little impact on teachers' school practices. Training mathematics teachers for primary schools, in particular, is seen as the most neglected and "the weakest link [...] in mathematics education" (Hungerford, 1994).

There is a reported issue of both poor background knowledge as well as poor mathematics teaching methods among pre-service teachers. Rosas and Campbell (2010) examined three undergraduate mathematics courses at a teacher-training institution in Ohio and found over three-quarters of the coursework was taught at the basic level, making student teachers leave their training with a limited understanding of mathematics. Floden and Menikeetti (2005) earlier also found that teachers could not articulate important concepts, arguing that "if the ability to explain basic concepts is important for teaching, then the subject matter courses teachers now typically take leave a large fraction of teachers without important subject matter knowledge" (p. 283).

\section{Mathematics Teaching and Learning in the Vietnamese Primary School}

Mathematics literacy is an essential component of Vietnam's general education across all school grades and is a compulsory paper in all high-stakes examinations in Vietnam, including the national entrance examination that provides access to higher education. At the primary school level, mathematics is considered important for developing students' interest in the subject in their later school years and to their achievement in many other subjects. It, therefore, occupies a significant share of classroom instruction at the primary school level (Table 2). The core mathematical content for the primary school curriculum aims to familiarise students with numbers, patterns, shapes, and the use of local reasoning and problem-solving skills. With this, the subject is considered to lay the foundation for the development of concepts, skills and thinking strategies required for students' further schooling and future learning (Tran, Nguyen, Le, \& Phan, 2019). Equally important, it is also expected that students will develop the ability to think critically, solve simple real-life situations, and form a proactive and creative learning attitude (Dao, Pham, \& Hoang, 2006).

Due to its significance, mathematics teaching in Vietnam has undergone various reforms in the hopes of improving teaching and learning quality. A new mathematics curriculum was introduced in 2000. This new curriculum emphasises the development of knowledge and skills relevant to students' lives in the community and practical thinking and studying methods, particularly problem-solving competencies and active learning. The mathematics textbook and curriculum reform recently initiated country-wide in 
2018 reiterated the aim to develop students' mathematical reasoning, modelling, problem-solving, mathematical communication, and the competence to use mathematical tools and media with more clearly articulated efforts (Ministry of Education and Training, 2018b). The Realistic Mathematics Education (RME) policy extensively promoted since 2013 is also hoped to contribute to major adjustments in Vietnamese mathematics education.

Upgrading teacher quality has been recognised as the key driving factor to success under these new initiatives. However, many Vietnamese educators and experts consider previous reforms as being largely superficial and not yet meeting the desired changes in mathematics teaching and learning (Nguyen et al., 2019). According to Do (2000), school mathematics lessons and assessments still offer few real world examples and applications. Mathematics teaching is dominated by teachers' lecturing, explaining, illustrating, imparting content and knowledge, and frequently incidentally questioning. As commented by Nemenzo et al. (2017), $90 \%$ of the time in mathematics class is spent on wholeclass teaching, $8 \%$ on individual work and $2 \%$ on group work. It is further added that providing students with "sufficient tricks to pass and get good results in mathematics examinations" (Le, 2006, p. 173) is still the actual goal of school mathematics teaching.

There are "bitter" lessons to be learnt from previous teaching reforms. The curriculum reform in 2000, for example, excluded teacher-training institutions from retraining and professional development of mathematics teachers and instead exercised a top-down approach from MOET, involving only local departments of education and training in the task of retraining teachers. Observing the effectiveness of the 2000 reform, the National Institute for Education Strategy and Curriculum Development (NIESAC) noted that around $60 \%$ of primary school teachers were left delivering the new curriculum and modifying their teaching approaches in difficulty (Nhan Dan, 2010). There was also no strategy for developing for mathematics teachers the competence of assessing student learning outcomes, especially by means of formative assessments (Le \& Nguyen, 2018).

Vietnam operates a career-based system in which teachers are recruited at a relatively young age - after they complete a teacher education programme at a teacher-training institution. Teachers remain in the civil service system throughout their working life. This is as opposed to a position-based system where teachers are hired on a fixed, limited-term contract to assume specific teaching positions within an unpredictable career-long progression of assignments (Tatto, 2014). The strength of the career-based system that Vietnam employs is that there is intensive initial teacher preparation. However, the quality of teacher training is not often seen as being able to support teachers throughout their career life
(Nguyen et al., 2019). The country's teacher education practices are training primary school teachers as generalist teachers rather than competent mathematics teachers. This agrees with the literature regarding primary school mathematics teaching being the most neglected area and the weakest link in the general education system (Hungerford, 1994). The system needs to focus on and better equip for primary school teachers the knowledge and skills to teach and evaluate mathematics learning outcomes. It also requires serious and careful preparation in terms of initial education and professional development for mathematics teachers.

\section{METHODOLOGY}

\section{Research Design}

This study employed a mixed method approach, integrating both quantitative and qualitative data to cast light on the research problem. Quantitative data refer to a large-scale survey involving pre-service teachers. Qualitative data refer to in-depth interviews with teacher trainers who were in direct engagement with training pre-service primary school teachers. The study employed an explanatory sequential design, with the quantitative data being collected and analysed first and then the qualitative data collection and analysis following up in the second phase before interpretations were made by connecting both data sources in the final phase.

As explained above, this paper reports the findings of the first stage of a teacher-upskill project conducted in 2018. There were two main tasks in this first stage, namely (a) identifying the professional competencies expected of Vietnamese teachers teaching mathematics at primary school and (b) examining the extent to which courses at teacher-training universities prepared preservice teachers with those competencies. The first task required a review of the literature on mathematics literacy, MPCK for mathematics teachers, and mathematics teaching practices in the context of primary school education. The outcome of this task was a tentative list of the professional competencies for Vietnamese teachers teaching mathematics at primary school. The tentative list was then consulted with stakeholders - in this case, teacher trainers, school administrators, and experienced in-service teachers - to confirm its relevance, currency, and validity. The second task involved designing and administering a survey and interviews on pre-service teachers' professional needs and teacher-training colleges' capacities in preparing for pre-service teachers the competencies identified.

\section{Research Sites and Research Participants}

The selection of the research site in this study employed the "purposeful sampling" technique (Martínez-Mesa, González-Chica, Duquia, Bonamigo, \& 
Table 3. Sampling

Tasks

Research participants

Identifying professional competencies required of primary 20 stakeholders, comprising 10 teacher trainers from five school teachers teaching mathematics teacher-training universities, 5 primary school administrators, and 5 experienced in-service primary schoolteachers

Exploring pre-service teachers' training needs and 493 pre-service teachers from the participating universities teacher-training institutions' capacities in developing the were invited to participate in a survey; 20 lecturers from the competencies expected of primary school teachers teaching mathematics participating universities were interviewed

Bastos, 2016) to ensure that the right research participants were involved and could provide an insight into the topic under investigation. The research site for this study spanned five teacher-training institutions. These were selected because they represented different localities and geographical areas in Vietnam and were established, well-resourced regional universities that had acquired a reputation for teacher education. Among these, Dong Thap University and An Giang University are from Southern Vietnam; Hung Vuong University, Hanoi Pedagogical University 2, and Thai Nguyen University of Education are based in the north of the country.

Firstly, the identification of the professional competencies required of primary school teachers teaching mathematics involved the participation of 20 stakeholders who consulted on the tentative competencies. The purposeful sampling technique was employed in this stage to select stakeholders that were the key stakeholders involved in mathematics teacher education. The 20 experts selected comprised ten teacher trainers from the five participating institutions, five school administrators, and five experienced in-service teachers currently working at primary school. Secondly, an investigation into pre-service teachers' training needs and teacher-training institutions' capacities in preparing pre-service teachers involved surveying 493 pre-service teachers and 20 lecturers from the participating universities. The pre-service teachers were in their final year of a 4-year teacher-training course. The lecturer participants that the study aimed for were respected and experienced teacher trainers. A summary of the sampling is provided in Table 3.

\section{Data Collection and Data Analysis}

The professional competencies expected of primary schoolteachers teaching mathematics were first identified through reviewing the literature. The tentative competencies were then sent to stakeholders to be reviewed individually prior to a whole-group discussion. The 20 stakeholders were convened in a 4 hour focus group meeting where they discussed the domains and indicators related to the tentative competencies. Due to practicality reasons, particularly since the stakeholders were from different cities, the meeting was organised a day following a professional development workshop for which these teacher-training institutions and primary school representatives were present. The professional competencies that were finalised in the focus group meeting contained six domains and 22 indicators. These will be presented as one finding in the Findings and Discussions part of this paper.

The tool to survey pre-service teachers' readiness to teach mathematics at primary school was a questionnaire developed by the researchers based on the professional competencies identified above. An online survey link containing the questionnaire was sent to faculty secretaries from the five participating institutions who then distributed the link to their final-year students. The faculty secretaries did not influence how the respondents responded to the survey and the respondents' responses were treated anonymously.

Valid responses were collected from 493 pre-service teachers (370 females and 123 males) from the five participating institutions. The questionnaire contained 4 demographic questions and 50 statements. Half of the statements required the respondents to rate on a 5-point Likert scale the extent to which training was provided for them to master certain skills and knowledge. For these items, a score of 1 indicated a professional area where no training was provided in the teacher-training course; scores of 2 to 5 indicated poor, adequate, good, and very good training provided, respectively. The remaining half of the statements asked the respondents to rate on a 5-point Likert scale their training needs. A score of 1 represented the areas of training that the respondents perceived to be the least necessary and a score of 5 represented the most necessary training topic for the respondents. Data collected from the survey were analysed by means of SPSS statistical software. A high reliability Cronbach alpha value was achieved (0.874), confirming that the questionnaire was reliable and consistent for use.

To explore the research topic from the perspectives of teacher-training institutions, 20 lecturers and trainers of pre-service teachers from the five institutions were invited to participate in a 45-minute interview. The interview length was to ensure most issues unexplored could be shared by the teachers and was referenced against interview length used in the literature (Loosveldt \& Beullens, 2013). During the interview, the lecturers 
Table 4. Domains and indicators in the mathematics professional competencies for Vietnamese primary school teachers

Domain 1. Understanding students' cognitive processing and psychological characteristics

1.1. Understanding primary school students' psychological and cognitive characteristics

1.2. Understanding students' mathematical thinking and mathematical language

1.3. Identifying students' zone of proximal development in mathematics learning and using that knowledge to inform teaching

Domain 2. Having a structural understanding of primary school mathematics

2.1. Having a structural understanding of mathematical content at the primary school level (algebra, geometry, measurement, statistics, and probability)

2.2. Understanding the connections in mathematical content across school levels

2.3. Knowing suitable techniques to solve mathematical problems at the primary school level

2.4. Understanding the mathematical basis of mathematical content in primary school curriculum and textbooks

Domain 3. Using appropriate mathematics teaching methods, tools, and strategies

3.1. Understanding the strengths and limitations of principles, techniques, and strategies used in primary school mathematics teaching

3.2. Applying appropriately different mathematical pedagogical techniques and processes

3.3. Selecting and designing teaching aids that suit teaching purposes

Domain 4. Designing and organising mathematics learning activities

4.1. Designing learning activities that align with the objectives, content, and pedagogies required for mathematics teaching at the primary school level

4.2. Designing teaching and learning activities that promote problem-solving and reasoning skills, particularly to formulate problems in authentic situations

4.3. Creating new mathematics problems for mathematics teaching at the primary school level

4.4. Developing for students the ability to express themselves, speak, and write clearly

Domain 5. Anticipating and addressing students' learning difficulties

5.1. Understanding students' approaches to learning and different individual learning styles

5.2. Diagnosing student learning difficulties in mathematics and their causes

5.3. Using suitable teaching strategies to address student learning difficulties

5.4. Handling pedagogical situations appropriately to create a friendly learning environment

Domain 6. Assessing learning outcomes

6.1. Understanding the aims, requirements, and principles of assessing mathematical literacy

6.2. Using appropriate methods to assess primary school students' learning outcomes

6.3. Using formative assessments

6.4. Using assessment outcomes to inform teaching

were asked to comment on the training of primary school teachers, especially in relation to developing for them the skills and knowledge needed for effective mathematics teaching. The lecturers were also asked questions about the challenges in training mathematics teaching knowledge and skills for pre-service teachers. The data collected were transcribed and coded in NVIVO into three main themes, namely (a) the successes in training pre-service teachers to teach mathematics at primary school, (b) the challenges in developing professional competencies for pre-service teachers, and (c) the changes needed to better prepare pre-service teachers for mathematics teaching at primary school.

\section{FINDINGS}

\section{Professional Competencies for Primary Schoolteachers Teaching Mathematics in Vietnam}

Drawing on the literature on mathematics teachers' professional competencies, the professional requirements for Vietnamese school teachers (Ministry of Education and Training, 2018a), and the particular context of primary school teaching in Vietnam, this study identifies six professional domains for primary school teachers teaching mathematics in Vietnam. The domains are specified in 22 indicators in Table 4 . Compared with competency models of mathematics teachers in the literature (for example, Barham, 2020; National Council of Teachers of Mathematics, 2000; National Research Council, 2001; Shulman, 1986, 1987), the professional competencies identified for Vietnamese teachers in this paper operationalise teachers' MCK and MPCK into domains of teachers' functioning. These domains cover teachers' concrete tasks, namely instructing, designing teaching and learning activities, assessing students' learning outcomes, and supporting students in particular relation to mathematics teaching at the primary school level. This structuring of the competencies has practical benefits in teacher evaluation and self-evaluation and in developing training topics for both pre-service and in-service teachers.

The competencies identified have concrete relevance and currency to the context of primary school mathematics teaching in Vietnam. The competencies address several important areas that are still neglected in teaching and teacher-training practices in the country and at the same time gear teachers' practices towards the 
new expectations articulated in Vietnam's recent education reforms.

Domain 1 - Understanding students' cognitive processing and psychological characteristics - is regarded as an important component among the desirable qualities for primary school mathematics teachers. Its importance is highlighted by the fact that there is often no dedicated module in teacher-training courses to prepare preservice teachers with an understanding of students' mathematical thinking and cognitive characteristics. Generally, teacher-training institutions only offer introductory modules on the psychological patterns of primary school students. This, however, does not enable mathematics teachers to effectively plan for mathematics lessons or handle students' learning difficulties in mathematics. Only through having the knowledge of how primary students learn mathematics and what their topics of interest are will teachers be able to deliver their mathematics instruction in an effective manner.

Domain 2 - Having a structural understanding of primary school mathematics - emphasises the importance of teachers having a structural understanding of mathematical concepts taught in the primary school setting. In this study, it is revealed that the MCK delivered to pre-service teachers is still heavily theoretical and abstract and lacks relevance to the content taught in the primary school classroom. The inclusion of Domain 2 in the competencies for mathematics teachers, therefore, serves to ensure that teachers have the right MCK, particularly to the extent that they can proficiently use their understanding of the mathematical basis and rationales underlying primary school's mathematical content to plan for their teaching, assessing, and supporting students.

Domain 3 - Using appropriate mathematics teaching methods, tools, and strategies - covers a wide range of expectations of mathematics teachers in pedagogical terms. The domain demands teachers have an understanding of the strengths and limitations of different principles, techniques, and strategies required to give mathematics instruction effectively and efficiently. It is argued that to best equip pre-service teachers with the competencies under Domain 3, teachers need to be able to understand and articulate what it means to be mathematically proficient.

Domain 4 - Designing and organising mathematics learning activities - first and foremost requires from primary school mathematics teachers the ability to design learning activities that align with the objectives, content, and pedagogies required for mathematics teaching at the primary school level. This is an existing core training topic in teacher-training courses in Vietnam. However, Domain 4 particularly emphasises the need for teachers to design teaching and learning activities that promote problem-solving and reasoning skills, particularly problem-solving in authentic situations, and develops for students the ability to express themselves by writing and speaking clearly. These later competencies in the domain are in alignment with aspirations for developing $21^{\text {st }}$-century skills, including problem-solving and critical thinking skills, for Vietnamese students (Nguyen et al., 2019).

Domain 5 - Anticipating and addressing students' learning difficulties - demands teachers have a sound understanding of the thinking and learning characteristics of primary school students so that they can anticipate and address students' cognitive challenges. A teacher necessarily needs to employ the competencies in the four domains above in order to build on strong skills in supporting students with their learning difficulties. At the same time, the teacher also needs to understand challenges that primary school students face when developing their mathematical proficiency, be it due to challenges related to conceptual understanding, procedural fluency, strategic competence, adaptive reasoning, or productive disposition. Each type of challenges will need a suitable approach.

The last domain - Assessing learning outcomes requires teachers to understand the aims, requirements, and principles of assessing mathematical literacy and then use appropriate methods to assess primary school students' learning outcomes and inform their teaching. The domain adds an element - using formative assessments - which is often neglected in the Vietnamese teaching culture, which is heavily exam-focused and examoriented. It has been acknowledged in the literature that while summative assessments are essential, changing teachers' and the system's perception of what assessments are for and about greatly influences teaching and learning practices. The competencies identified in Domain 6 are not only to inform teaching and learning but also to create positive learning experiences for students.

\section{Professional Learning Needs of Pre-Service Teachers}

Having identified the professional competencies expected of primary school mathematics teachers, by means of an online survey, the study moved onto exploring pre-service teachers' training needs and the extent to which teacher-training institutions responded to those needs. The demographic information of the preservice teachers who responded to the survey is given in Table 5. The purposeful sampling technique was employed in the study to ensure that all the respondents invited to participate in the study were in the final year of their training programme. The table shows that most respondents undertook their teacher-training course as their first degree-course experience and did not have prior experience with teaching or working with schoolaged students. This profile of the respondents highlights the fact that pre-service teachers heavily depend on their teacher-training programmes to be confident and ready in their future teaching task. The relevance, currency, 
Table 5. Profile of the surveyed pre-service teachers at the participating institutions

\begin{tabular}{|c|c|c|c|}
\hline Variables & & $\mathrm{n}$ & $\%$ \\
\hline \multirow[t]{2}{*}{ Gender } & Male & 370 & 75.1 \\
\hline & Female & 123 & 24.9 \\
\hline \multirow[t]{2}{*}{ Age in years } & $\leq 23$ & 258 & 52.3 \\
\hline & $\geq 24$ & 235 & 47.7 \\
\hline \multirow[t]{2}{*}{ Completed supervised observations } & Yes & 430 & 87.2 \\
\hline & No & 63 & 12.8 \\
\hline \multirow[t]{2}{*}{ Completed teaching practicum } & Yes & 269 & 54.6 \\
\hline & No & 224 & 45.4 \\
\hline \multirow[t]{2}{*}{ Prior teaching experience } & Yes & 33 & 6.7 \\
\hline & No & 460 & 93.3 \\
\hline \multirow[t]{2}{*}{ Prior professional experience working with school-aged children } & Yes & 0 & 0 \\
\hline & No & 493 & 100 \\
\hline Total sample & & 493 & 100 \\
\hline
\end{tabular}

Table 6. How university education is preparing for pre-service teachers' mathematics teaching as perceived by pre-service teachers $\left({ }^{*} \mathrm{M} 1=\right.$ mean score of responses to the training provided by teacher-training institutions; $\mathrm{M} 2=$ mean score out of 5 for pre-service teachers' training needs)

Domains

Domain 1. Understanding students' cognitive processing and psychological characteristics

1.1. Understanding primary school students' psychological and cognitive characteristics 3.52

1.2. Understanding students' mathematical thinking and mathematical language 3.88

1.3. Identifying students' zone of proximal development in mathematics learning and using that $2.91 \quad 3.78$ knowledge to inform teaching

Domain 2. Having a structural understanding of primary school mathematics

2.1. Having a structural understanding of mathematical content at the primary school level (algebra, $3.51 \quad 3.47$ geometry, measurement, statistics, and probability)

2.2. Understanding the connections in mathematical content across school levels

$3.42 \quad 3.98$

2.3. Knowing suitable techniques to solve mathematical problems at the primary school level

$3.68 \quad 3.01$

2.4. Understanding the mathematical basis of mathematical content in primary school curriculum and $3.85 \quad 3.55$ textbooks

Domain 3. Using appropriate mathematics teaching methods, tools, and strategies

3.1. Understanding the strengths and limitations of principles, techniques, and strategies used in $2.79 \quad 4.05$ primary school mathematics teaching

3.2. Applying appropriately different mathematical pedagogical techniques and processes $\quad 2.67 \quad 4.15$

3.3. Selecting and designing teaching aids that suit teaching purposes

Domain 4. Designing and organising mathematics learning activities

4.1. Designing learning activities that align with the objectives, content, and pedagogies required for $4.22 \quad 3.52$ mathematics teaching at the primary school level

4.2. Designing teaching and learning activities that promote problem-solving and reasoning skills, $2.16 \quad 4.78$
particularly to formulate problems in authentic situations

4.3. Creating new mathematics problems for mathematics teaching at the primary school level 3.57

4.4. Developing for students the ability to express themselves, speak and write clearly 3.113 .55

Domain 5. Anticipating and addressing students' learning difficulties

5.1. Understanding students' approaches to learning and different individual learning styles

5.2. Diagnosing student learning difficulties in mathematics and their causes

$2.45 \quad 4.22$

5.3. Using suitable teaching strategies to address student learning difficulties $\quad 2.75$

5.4. Handling pedagogical situations appropriately to create a friendly learning environment $\quad 3.80$

\section{Domain 6. Assessing learning outcomes}

6.1. Understanding the aims, requirements, and principles of assessing mathematical literacy $\quad 3.05$

6.2. Using appropriate methods to assess primary school students' learning outcomes 3.82

$\begin{array}{lr}\text { 6.3. Using formative assessments } & 2.56 \quad 4.35\end{array}$

6.4. Using assessment outcomes to inform teaching

$3.26 \quad 4.21$

and usefulness of training content are of utmost significance.

Table 6 reports two types of data, firstly pre-service teachers' responses to the survey questions regarding the extent to which sufficient training was provided for

them to master the competencies identified and secondly pre-services' responses to the survey questions about their training needs. The mean scores are reported for a scale out of 5 . 
The study found that a large number of pre-service teachers reported receiving adequate training on identifying lesson objectives and content, analysing curriculum requirements, and designing teaching and learning activities that meet the lesson's objectives. Preservice teachers were also self-perceived to lack readiness in terms of handling mathematical concepts and methods suitable for the learning of students at the primary school level. The challenge was seen to be attributed to the lack of the capacity to judge the mathematics competencies required by students to solve mathematics problems and to diagnose students' misconceptions and error procedures. Mathematical content was still treated as formal elements from a scientific discipline while pre-service teachers were provided with little opportunities to make connections between what they learnt in their university programmes and their future teaching practice. The selfreported inadequate level of readiness to teach mathematics by Vietnamese pre-service teachers gives a strong indication that additional mathematics and pedagogy coursework is needed in teacher-training courses.

Following the survey with pre-service teachers, interviews were conducted with lecturers at the five teacher education institutions. The interviews revealed several major causes that challenged the development of mathematics teaching competencies for pre-service teachers. These included a lack of awareness and motivation to develop these competencies among preservice teachers themselves. However, more importantly, the interviewed lecturers perceived that teacher training courses insufficiently covered the depth of MCK and MPCK for pre-service teachers to effectively perform their teaching duties. Pre-service teachers were reported to be trained to teach many subjects at primary school. Therefore, the total training time was to be divided up and allocated to different modules to develop the teaching capacity in different subjects. This did not allow the MCK content in the training programmes to go in sufficient depth to allow for confidence among pre-service teachers. Many preservice teachers also voiced concerns about being poorly equipped with mathematics teaching methodology. They argued that while several methodology modules in their course covered pedagogy-related topics, these were overtly theoretical. Lecturers at teacher-training institutions, meanwhile, admitted that they did not focus on developing MPCK for pre-service teachers, assuming that the task should be performed by lecturers teaching general pedagogy modules.

\section{DISCUSSIONS AND CONCLUSION}

Findings from this study reveal that the training of mathematics teachers in Vietnam has not moved very far in terms of upgrading the professional competencies for pre-service teachers to effectively deliver mathematics instruction. This study has identified six domains of practice and four areas that Vietnamese pre-service teachers are not well-trained in. The findings indicated that Vietnamese pre-service teachers were adequately trained in terms of mathematical content knowledge yet were less ready in terms of mathematical teaching pedagogies. MPCK was reportedly an often-neglected area at teacher-training colleges and was subsumed under general pedagogical content knowledge. This is an issue that has been identified in the literature as the missing link between teacher training offered by teachertraining colleges and the reality of school teaching (Saberi \& EErami, 2016; Vasagar, 2010). Pre-service teachers, for example, believed that they received insignificant training on developing for school students the ability to apply mathematics in solving real-life problems, which is aspired for under Vietnam's policy statements for Realistic Mathematics Education (RME) (Nguyen et al., 2019). In the Literature Review section of this paper, the five representations of mathematical proficiency have been identified, namely conceptual understanding, procedural fluency, strategic competence, adaptive reasoning, and productive disposition (Polly, 2011; Shriki \& Lavy, 2012). Recently, Tran et al. (2019) raise the issue of slow learners accounting for a third of the student number in a typical Vietnamese primary classroom. This makes the capacity to diagnose student learning difficulties in mathematics and their causes and use suitable teaching strategies to address student learning difficulties highly relevant to the Vietnamese primary school teaching context. It is important that Vietnamese pre-service teachers are trained to identify what pedagogical strategies and procedures are suitable for targeting a particular aspect of mathematical proficiency.

The implications to be drawn from this study share agreement with the implications in the literature concerning the importance of explicitly training preservice teachers in mathematics pedagogy and content. The TEDS-M study on teacher education, for example, found that primary level teachers who receive more training on university and school level mathematics perform better in content and pedagogical knowledge tests (Tatto, 2014). In other words, future primary teachers who are trained as mathematics specialists scored higher in both the MCK and MPCK than those only trained to teach as primary generalist teachers (Tatto, 2014). Lester, McCormick, and Kapusuz (2004), when examining the contribution of mathematics preservice programmes on teacher practices, also found that the more mathematics studied by pre-service primary teachers, the more confidence teachers can assume in their mathematical content knowledge and pedagogies. For this study, data from the survey and interviews as reported above enables the study to identify three main areas that teacher-training institutions in Vietnam need to support pre-service teachers with, namely: 
- Understanding the mathematical basis and rationales of mathematical content in the primary school curriculum and textbooks

- Understanding primary school students' learning and cognitive characteristics; diagnosing and addressing cognitive barriers experienced by students

- Designing authentic mathematics activities and tasks

This study argues that for pre-service teachers to be able to effectively teach mathematics lessons, the training of mathematical content and methods needs to be explicitly included in teacher-training programmes. Having identified areas in which pre-service teachers need support to develop more readiness and confidence in their teaching, the study proposes the following training activities to be incorporated into teachertraining courses not only at the participating teachertraining universities but also at other teacher-training institutions that have experienced similar issues in developing mathematics teachers' competencies. Within the scope of this paper, these intervention strategies are only proposed.

In terms of enhancing mathematical content knowledge for pre-service teachers, the following activities should be introduced in teacher-training programmes for Vietnamese mathematics teachers:

- Identifying all mathematics topics in the primary school mathematics curriculum

- Identifying types of mathematics problems, modelling, reasoning, or tools

- Formulating (in graphic forms) the development and relationship between different topics

- Identifying the mathematical basis and rationales underlying key concepts

- Identifying strategies to find solutions for key types of mathematics problems.

Meanwhile, to enhance knowledge of learners and learners' learning difficulties for pre-service teachers in Vietnam, the following activities are of prioritised:

- Identifying learner characteristics for each grade at the primary school level

- Identifying skills and knowledge targeted by primary school mathematics

- Identifying objectives and expected learning outcomes for each type of mathematics topics

- Developing strategies (e.g., using structured questions) to identify students' learning goals

- For each mathematics topics, identifying common problems experienced by students and ways to support students.

Finally, it is important to promote Realistic Mathematics Education (RME) for pre-service teachers since this is a focus and also an aim of Vietnam's mathematics education. The following activities are identified as important:

- Understanding students' socio-educational context

- Designing mathematics problems or situations relevant or familiar to students' learning, social needs, family, school, and social settings

- Understanding the competency-based approach and designing lessons using that approach.

Author contributions: All authors have sufficiently contributed to the study, and agreed with the results and conclusions.

Funding: No funding source is reported for this study.

Compliance with ethical standards: The authors assures that this research paper was done in compliance with Ethical Standards.

Declaration of interest: The authors declare that they have no conflict of interest in this research.

\section{REFERENCES}

Ball, D. L. (2003). What mathematical knowledge is needed for teaching mathematics [Paper presentation]. Secretary's Summit on Mathematics, US Department of Education, Washington, DC, 6 February.

Barham, A. I. (2020). Exploring in-service mathematics teachers' perceived professional development needs related to the Strands of Mathematical Proficiency (SMP). Eurasia Journal of Mathematics, Science and Technology Education, 16(10), 1-18. https:// doi.org/10.29333/ejmste/8399

Baumert, J., Kunter, M., Blum, W., Brunner, M., Voss, T., Jordan, A., Klusmann, Uta, Krauss, S, Neubrand, M, \& Tsai, Y.-M. (2010). Teachers' mathematical knowledge, cognitive activation in the classroom, and student progress. American Educational Research Journal, 47(1), 133-180. https://doi.org/10.3102/ 0002831209345157

Blömeke, S., Hsieh, F.-J., Kaiser, G., \& Schmidt, W. (2014). International perspectives on teacher knowledge, beliefs and opportunities to learn. Teachers education and development study in mathematics (TEDS-M) results. Springer. https:// doi.org/10.1007/978-94007-6437-8

Campbell, P. F., Nishio, M., Smith, T. M., Clark, L. M., Conant, D. L., Rust, A. H., Depiper, J. N., Frank, T. J., Griffin, M J., \& Choi, Y. (2014). The relationship between teachers' mathematical content and pedagogical knowledge, teachers' perceptions, and student achievement. Journal for Research in Mathematics Education, 45(4), 419-459. https://doi.org/10.5951/jresematheduc.45.4.0419

Dao, T., Pham, T. T., \& Hoang, T. B. (2006). Thực hành phương pháp dạy học toán ở tiểu học [Mathematics teaching methods for primary school level]. Da Nang Publishing House. 
Do, D. (2000). Mathematics teaching and learning in Vietnam. Center for Curriculum Development and Teaching Methodology, National Institute for Educational Sciences.

Do, N. H. (2020). Nâng cao chất lượng đội ngũ nhà giáo trong giai đoạn hiện nay [Improving teacher quality in the current period]. Trang thông tin điện tử Ban tuyên giáo Tỉnh ủy Hưng Yên [Hung Yen Provincial Party Committee], 12 March, 2020.

Döhrmann, M., Kaiser, G., \& Blömeke, S. (2012). The conceptualisation of mathematics competencies in the international teacher education study TEDS-M. ZDM Mathematics Education, 44, 325-340. https: / / doi.org/10.1007/s11858-012-0432-z

Floden, R., \& Menikeetti, M. (2005). Research on the effects of coursework in the arts and sciences and in the foundations of education. In M. Cochran-Smith \& K. Zeichner (Eds.), Studying teacher education: The report of the AERA panel on research and teacher education (pp. 261-309). Lawrence Erlbaum Associates Publishers.

Hattie, J. (2003). Teachers make a difference, what is the research evidence? [Paper presentation]. Building teacher quality: What does the research tell us, Australian Council for Educational Research (ACER) Research Conference, Melbourne, Australia, 19-21 October.

Hauk, S., Toney, A., Jackson, B., Nair, R., \& Tsay, J.-J. (2014). Developing a model of pedagogical content knowledge for secondary and post-secondary mathematics instruction. Dialogic Pedagogy, 2, 16-40. https://doi.org/10.5195/dpj.2014.40

Hungerford, T. W. (1994). Future elementary teachers: The neglected constituency. The American Mathematical Monthly, 101(1), 15-21. https:/ / doi.org/10.1080/00029890.1994.11996898

Kaiser, G., Blömeke, S., Koenig, J., Busse, A., Doehrmann, M., \& Hoth, J. (2017). Professional competencies of (prospective) mathematics teachers-Cognitive versus situated approaches. Educational Studies in Mathematics, 94(2), 161-182. https: / / doi.org/10.1007/s10649-016-9713-8

Le, A. T. (2006). Applying Realistic Mathematics Education in Vietnam: Teaching middle school geometry. (Doctoral dissertation). Universität Potsdam, Potsdam.

Le, H. T. T., \& Nguyen, C. H. (2018). Vietnam primary school students' ability of applying mathematics knowledge into real life. Advances in Social Sciences Research Journal, 5(5), 67-75. https://doi.org/ 10.14738 /assrj.55.4531

Lester, F. K., McCormick, K., \& Kapusuz, A. (2004). Preservice teachers' beliefs about the nature of mathematics. In B. Clarke, D. M. Clarke, G. Emanuelsson, B. Johansson, D. V. Lambdin, F. K.
Lester, A. Wallby, \& K. Wallby (Eds.), International Perspectives on Learning and Teaching Mathematics (pp. 555-567). Goteborg University: National Centre for Mathematics Education.

Leung, F. K. S. (2006). Mathematics education in East Asia and the West: Does culture matter? In F. K. S. Leung, K.-D. Graf, \& F. J. Lopez-Real (Eds.), Mathematics education in different cultural traditions: A comparative study of East Asia and the West. The 13th ICMI study (pp. 21-46). Springer. https://doi.org/ 10.1007/0-387-29723-5_2

Loosveldt, G., \& Beullens, K. (2013). 'How long will it take?'An analysis of interview length in the fifth round of the European Social Survey. Survey Research Methods, 7(2), 69-78.

Martínez-Mesa, J., González-Chica, D. A., Duquia, R. P., Bonamigo, R. R., \& Bastos, J. L. (2016). Sampling: How to select participants in my research study? Anais brasileiros de dermatologia, 91(3), 326-330. https:/ / doi.org/10.1590/abd1806-4841.20165254

Ministry of Education and Training. (2018a). Chuẩn nghề nghiệp giáo viên cơ sở giáo dục phổ thông [Professional standards for school teachers]. Ministry of Education and Training.

Ministry of Education and Training. (2018b). Thông tu 32/2018/TT-BGDĐT của Bộ Giáo dục và Đào tạo về việc ban hành Chương trình giáo dục phổ thông [Circular 32/2018 /TT-BGDDT promulgating the general education programme]. Ministry of Education and Training.

Moore, R., \& Rossiter, J. (2018). Young Lives school surveys, 2016-17: The design and development of teacher measures in Ethiopia, India and Vietnam. Young Lives, Oxford Department of International Development (ODID), University of Oxford.

National Council of Teachers of Mathematics. (2000). Principles and standards for school mathematics. National Council of Teachers of Mathematics.

National Research Council. (2001). Adding it up: Helping children learn mathematics. National Academies Press.

Nemenzo, F. R., Isoda, M., Inprasitha, M., Thinwiangthong, S., Changsri, N., Boonsena, N., Roth, C., Lin, M., Anothay, S., Channgakham, P., Thanh, N. C., Vu-Nhu, T.-H., \& Nguyen, P. T. (2017). National presentations of lower Mekong sub-region countries. In G. Kaiser (Ed.), Proceedings of the 13th International Congress on Mathematical Education ICME-13 (pp. 361-366). Springer. https:/ / doi.org/10.1007/978-3-319-62597-3_26

Nguyen, T. T., Trinh, T. P., \& Tran, T. (2019). Realistic mathematics education (RME) and didactical situations in mathematics (DSM) in the context of education reform in Vietnam. Journal of Physics: 
Conference Series, 1340(012032), 1-14. https://doi. org/10.1088/1742-6596/1340/1/012032

Nhan Dan. (2010). Đánh giá chất lượng chương trình, sách giáo khoa tiểu học, trung học cơ sở mới [Evaluating the quality of the new curriculum and new series of textbooks for primary and secondary school levels]. Nhan Dan News, 19 July.

OECD. (1999). Measuring student knowledge and skills: A new framework for assessment. OECD. https:/ / doi.org/10.1787/9789264173125-en

OECD. (2010). PISA 2009 results: What makes a school successful? Resources, policies and practices (Vol. 4). OECD. https://doi.org/10.1787/9789264091559en

Polly, D. (2011). Examining teachers' enactment of technological pedagogical and content knowledge (TPACK) in their mathematics teaching after technology integration professional development. Journal of Computers in Mathematics and Science Teaching, 30(1), 37-59.

Richardson, V. (1996). The role of attitudes and beliefs in learning to teach. In J. Sikula, T. Buttery, \& E. Guyton (Eds.), Handbook of research on teacher education (pp. 102-119). Macmillan.

Rosas, C., \& Campbell, L. (2010). Who's teaching math to our most needy students? A descriptive study. Teacher Education and Special Education, 33(2), 102113. https:// doi.org/10.1177/0888406409357537

Saberi, S., \& EErami, A. (2016). The investigation of strengths and weaknesses of primary school teachers in mathematics knowledge. American Journal of Educational Research, 4(8), 648-651.

Shriki, A., \& Lavy, I. (2012). Perceptions of Israeli mathematics teachers regarding their professional development needs. Professional Development in Education, 38(3), 411-433. https:/ / doi.org/10.1080/ 19415257.2011.626062

Shulman, L. S. (1986). Those who understand: Knowledge growth in teaching. Educational
Researcher, 15(2), 4-14. https://doi.org/10.3102/ 0013189X015002004

Shulman, L. S. (1987). Knowledge and teaching: Foundations of the new reform. Harvard Educational Research, 57, 1-22. https://doi.org/10.17763/ haer.57.1.j463w79r56455411

Superfine, A. C., \& Li, W. (2014). Developing mathematical knowledge for teaching teachers: A model for the professional development of teacher educators. Issues in Teacher Education, 23(1), 113-132.

Tatto, M. (2014). Teacher Education Development StudyMathematics (TEDS-M). In S. Lerman (Ed.), Encyclopedia of mathematics education (pp. 586-592). Springer. $\quad$ https://doi.org/10.1007/978-94-0074978-8_151

Teacher Education Ministerial Advisory Group. (2014). Issues paper. Australian Government.

Tran, T., Nguyen, T. T. T., Le, T. T. T., \& Phan, T. A. (2019). Slow learners in mathematics classes: The experience of Vietnamese primary education. Education 3-13, 48(5), 580-596. https://doi.org/ 10.1080/03004279.2019.1633375

Vasagar, J. (2010). Weak teachers the biggest problem in schools. The Guardian, 24 November.

Vietnam Ministry of Education and Training. (2018). Thông tu 20/2018/TT-BGDĐT ban hành quy định chuẩn nghề nghiệp giáo viên cơ sở giáo dục phổ thông [Circular No. 20/2018/TT-BDGDT on professional standards for schoolteachers]. MOET.

Vietnam National Assembly. (2016). Resolution No. 142/2016/QH13 on the five-year Socio-economic Development Plan 2016-2020. The National Assembly.

World Bank. (2014). Vietnam Renovation of General Education Project (P150058). Project information document: Coherent curriculum and assessment for improved teaching outcomes. World Bank.

\section{http://www.ejmste.com}

